Copyright (C) 2021 by Cherkas Global University

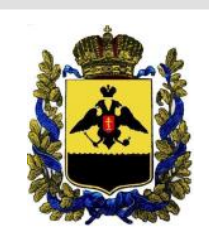

Published in the USA

Bylye Gody

Has been issued since 2006.

E-ISSN: $2310-0028$

2021. 16(4): 1835-1848

DOI: $10.13187 /$ bg.2021.4.1835

Journal homepage:

https://bg.cherkasgu.press

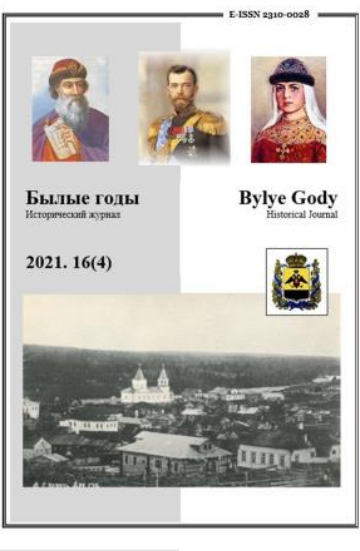

\title{
Professionalization, Democratization, and Nativization of the Justice of the Peace Corps in the South-Western Provinces in the Late Imperial Russia
}

Igor I. Verniaev a, *

${ }^{a}$ St. Petersburg State University, Russian Federation

\section{Abstract}

The Justice of the Peace (hereinafter referred to as «JP») court existed in the provinces of the SouthWestern Land (Kiev, Volyn, and Podolsk) for 45 years from 1872 to the end of the empire. Multiethnicity was one of the main factors of functioning of the JP courts there. Staffing of JP courts became a challenge for the imperial judicial powers. JPs had to be professionals in the judicial sphere, to have knowledge of regional specifics, to remain loyal to the imperial center leading the mission of legal integration of the frontier. To what extent was it possible to comply with these criteria? To answer this question, the article turns to official documents and narrative materials, such as personal files of JPs, annual lists of judges, audit materials, memoirs, and periodicals. Their analysis indicates three interrelated processes that took place in the late 19th - early 20th century: 1) the JP's corps was becoming more and more democratic in its composition; more and more representatives of the urban and rural middle and lower classes were being appointed as JPs, while the share of nobles was decreasing sharply; 2) the professional level of the judicial corps was improving, the share of judges with higher legal education was rapidly increasing with regional universities, primarily the Kiev University of St. Vladimir, playing a great role in this process. 3) the share of JPs of Ukrainian origins started to increase in the 1890s; contrary, the share of Russians from inner provinces was on decline; so there was an intensive process of nativization of the judicial corps. Thus, the study demonstrates that at the beginning of the 2oth century, a corps of professional judges had formed in the region. The majority of them were connected with the Ukrainian provinces in personal, educational, and career terms. The results of the changes are evaluated by the criterion of the dynamics of the demand for JP courts by the broad strata of the population in the region.

Keywords: The Russian Empire, the South-Western Land, the Justice of the Peace court, changes in the estate, educational, confessional and ethnic composition of the judicial corps, nativization and professionalization of the judicial sphere.

\section{1. Введение}

Мировой суд был одним из ключевых элементов судебной реформы 1864 года. Согласно Судебным Уставам, компетенция мировой юстиции как местного общегражданского суда распространялась на относительно мелкие уголовные и гражданские дела. Но такие дела, как правило, были массовыми, и их число росло во всех регионах империи (Верняев, 2021: 95-113). Являясь массовым институтом, мировые суды должны были способствовать установлению правового порядка, повышению экономической активности, эффективному разрешению местных конфликтов и в итоге формированию гражданского общества поверх классовых, этнических и религиозных границ. Рассматривая множество судебных дел в своем участке, мировой судья регулярно взаимодействовал с разными категориями жителей. Следовательно, он должен был хорошо знать местное сообщество, условия его жизни, правовые воззрения, язык и культуру. Во внутренних губерниях это обеспечивалось выборной системой. Мировых судей здесь выбирало земство. На окраинах империи,

${ }^{*}$ Corresponding author

E-mail addresses: i.verniaev@spbu.ru (I.I. Verniaev) 
помимо обеспечения правосудия, на мировые суды возлагалась миссия культурной, правовой и институциональной интеграции, объединения имперского пространства. Учитывая эту миссию, отсутствие земств и полиэтнический состав имперских окраин, правительство само назначало здесь судей. Необходимость сочетать такие критерии, как профессиональная юридическая подготовка, имущественный ценз, лояльность центральному правительству и хорошее знание регионального и местного контекста, определяла трудности при отборе персонала для мировых судов окраин.

В этой статье исследуются изменения корпуса мировых судей юго-западных губерний (Киевской, Волынской и Подольской) в сословном, конфессиональном, этническом и образовательном отношении. Кто творил местный имперский суд в Правобережной Украине в конце XIX - начале XX веков? Были ли связаны эти люди с регионом по рождению, месту образования, карьере? Насколько эти судебные должности были доступны для разных категорий коренных жителей украинских губерний? Из каких социальных слоев происходили мировые судьи? Какова была их этническая и религиозная принадлежность? Какую роль играли региональные университеты в формировании судейского сообщества? Как все эти параметры изменялись?

Анализ количественных и описательных данных позволил ответить на основной вопрос этой статьи: происходила ли в конце имперского периода своего рода региональная «коренизация» имперских кадров на уровне мировой юстиции? Понятие «коренизация» ассоциируется обычно с раннесоветской политикой в национальных регионах страны в 1920-е - начале 1930-х гг., которая предполагала, в частности, формирование профессиональных кадров из числа представителей коренного населения. Но не наметились ли подобные тенденции уже в позднеимперский период и, в частности, в судебной системе?

\section{2. Материалы и методы}

В статье использованы, главным образом, списки чинов Министерства юстиции. Они позволили выявить изменения в части религиозной аффилиации, этнической и сословной принадлежности, наличия и места нахождения недвижимости, места получения образования, сроков службы в ведомстве Министерства юстиции и на должности мирового судьи. В качестве дополнительных источников для изучения судейских карьер и характера связи судей с исследуемым регионом использовались их личные дела (формулярные списки), хранящиеся в РГИА, а также другие материалы - отчеты о ревизиях, воспоминания. Использованы методы статистической обработки материала и, в частности, осуществлен расчет индекса этнического представительства ${ }^{1}$.

\section{3. Обсуждение}

Б.Н. Миронов разработал и применил на общеимперском уровне методику исследования представительства этнических групп в управлении и сферах занятости. Полученные результаты он сопоставил с данными об этническом представительстве на разных этапах истории Советского Союза, что позволило изучить представительство и степень дискриминации в динамике. Историк пришел, в частности, к выводу, что этнополитическая дискриминация в империи не была столь существенной, чтобы стать главной причиной распада Российской империи (Миронов, 2020; Миронов, 2021 ). Разработанные Б.Н. Мироновым подходы и полученные общестрановые результаты позволяют решать более частные вопросы на конкретном региональном материале, на разных уровнях, в разных ветвях структур управления и отраслях занятости, исследовать конкретные механизмы смоделированных исследователем макро-процессов.

В свой работе канадский историк С. Величенко поставил вопрос о том, кто управлял Российской империей на окраинах и, в частности, в украинских губерниях. Назначались ли и в какой мере на административные должности местные уроженцы, или в имперском управлении региона преобладали выходцы из других губерний? В какой мере большевистская политика коренизации административного корпуса была новацией или она имела истоки в имперский период? В поисках ответа автор исследовал этнический состав верхнего и среднего уровня администрации украинских провинций империи в XIX - начале XX вв. Этническая принадлежность чиновников определялась им в основном на основании антропонимики. С. Величенко пришел к выводу о том, что на самых верхних уровнях региональных и губернских администраций в течение XIX - начала XX вв. происходило существенное сокращение чиновников украинского происхождения (с 50 \% в 1800 г. до $13 \%$ в 1914 г.) при росте доли русских и немцев - выходцев соответственно из внутренних и остзейских губерний. Но на среднем уровне администрации доля украинцев к началу ХХ в. составляла около половины. Сокращение в этой части администрации также было, но

\footnotetext{
${ }^{1}$ Индекс вычисляется делением процентной доли представителей той или иной этнической группы в исследуемой сфере (например, город в целом, институты управления, отрасль занятости и др.) на процентную долю представителей этой группы во всем населении административной территории, среди всех занятых, среди избирателей и т.д. (в зависимости от задачи и контекста). Индекс дает сводную количественную оценку, где 1,0 обозначает пропорциональное представительство, более 1,0 - избыточное представительство, а менее 1,0 - недостаточное представительство.
} 
несущественное. С 1905 г. наблюдался небольшой рост этой доли. При этом доля украинцев на средних уровнях администрации была хотя и ниже их доли во всем населении, но соразмерна их доле среди горожан и дворянства (Velychenko, 1995).

Поставленные вопросы в отношении судейского корпуса мировой юстиции Российской империи исследованы недостаточно. Советский историк П.Ф. Щербина в своей работе о судебной реформе в Правобережной Украине уделил внимание принципам и процедуре назначения мировых судей, но не осуществил анализ персонального состава мировых судов. Его оценка мировой юстиции региона отличается тенденциозностью (Щербина, 1974). Современный украинский историк В.С. Панченко исследовал ряд характеристик (сословие, образование, религиозная принадлежность, возраст) мировых судей Волынской губернии в 1872-1917 гг. Свои выводы исследователь основывал на выборочном анализе персональных дел (Панченко, 2013). Однако в работе отсутствует анализ изменений. Автор суммировал данные за разные годы как синхронные, что снижает качество этого исследования.

\section{4. Результаты}

Сословный состав корпуса мировых судей региона претерпел существенные изменения. Доступные данные за 1890-1913 гг. представлены в Таблице 1.

Таблица 1. Динамика сословного состава корпуса мировых судей Юго-Западного края, \% (Список чинам, 1890; Список чинам, 1900; Список чинам, 1910; Список чинам, 1913)

\begin{tabular}{|c|c|c|c|c|c|c|c|c|c|c|c|c|c|}
\hline $\begin{array}{l}\text { Губернии и } \\
\text { край в целом }\end{array}$ & Год & 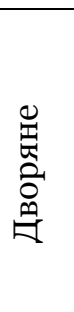 & 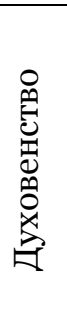 & 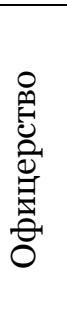 & 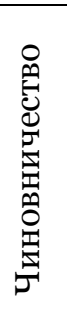 & 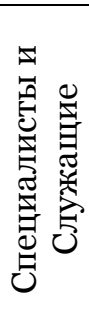 & 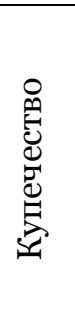 & 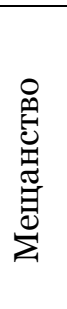 & 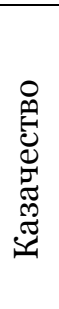 & 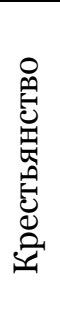 & 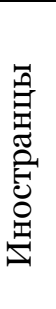 & 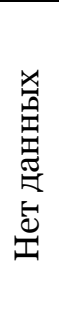 & $\begin{array}{l}0 \\
0 \\
0 \\
:\end{array}$ \\
\hline \multirow[t]{4}{*}{ Киевская } & 1890 & 54 & 21 & 11 & 3 & 2 & 2 & 3 & 2 & O & 2 & O & 100 \\
\hline & 1900 & 47 & 20 & 8 & 5 & 2 & 8 & 5 & 2 & 5 & 2 & o & 100 \\
\hline & 1910 & 29 & 24 & 22 & 6 & $\mathrm{O}$ & 3 & 10 & 1 & 4 & 1 & O & 100 \\
\hline & 1913 & 28 & 23 & 21 & 10 & 0 & 6 & 8 & 0 & 3 & 1 & O & 100 \\
\hline \multirow[t]{4}{*}{ Волынская } & 1890 & 47 & 21 & 19 & o & o & 9 & 2 & o & o & o & 2 & 100 \\
\hline & 1900 & 28 & 35 & 14 & 9 & 0 & 2 & 9 & 4 & $\mathrm{O}$ & $\mathrm{O}$ & $\mathrm{O}$ & 100 \\
\hline & 1910 & 18 & 27 & 18 & 5 & 2 & 5 & 18 & 4 & 4 & o & o & 100 \\
\hline & 1913 & 17 & 26 & 15 & 9 & 2 & $\mathrm{O}$ & 17 & 6 & 6 & 2 & $\mathrm{O}$ & 100 \\
\hline \multirow[t]{4}{*}{ Подольская } & 1890 & 49 & 33 & 9 & 0 & 0 & 4 & 2 & 2 & $\mathrm{O}$ & 0 & 2 & 100 \\
\hline & 1900 & 43 & 22 & 15 & 0 & $\mathrm{O}$ & 6 & 7 & o & 7 & O & 0 & 100 \\
\hline & 1910 & 37 & 21 & 21 & 4 & o & 4 & 0 & O & 6 & 8 & $\mathrm{O}$ & 100 \\
\hline & 1913 & 33 & 24 & 20 & 4 & 4 & 2 & 7 & 0 & 4 & 2 & 0 & 100 \\
\hline \multirow{4}{*}{$\begin{array}{l}\text { Юго- } \\
\text { Западный } \\
\text { край в целом }\end{array}$} & 1890 & 50 & 25 & 13 & 1 & 1 & 4 & 2 & 1 & 0 & 1 & 1 & 100 \\
\hline & 1900 & 40 & 25 & 12 & 5 & 1 & 5 & 7 & 2 & 4 & 1 & 0 & 100 \\
\hline & 1910 & 28 & 24 & 21 & 5 & 1 & 4 & 9 & 2 & 4 & 3 & 0 & 100 \\
\hline & 1913 & 26 & 24 & 19 & 8 & 2 & 3 & 11 & 2 & 4 & 2 & 0 & 100 \\
\hline
\end{tabular}

За рассматриваемый период почти в два раза - с половины до четверти - сократилась доля выходцев из дворянства среди мировых судей. Если в 1890 г. по Юго-Западному краю в целом их было 50 \%, то в 1913 г. - 26 \%. Особенно существенным было сокращение в Волынской губернии - с 47 до 17 \%. Доля выходцев из духовенства среди судей региона оставалась стабильной и значительной - около четверти всех мировых судей. В два раза - до $20 \%$ - по региону выросла доля выходцев из семей офицеров разного ранга (в списках сословная принадлежность определялась как «обер-офицерский сын» и «штаб-офицерский сын»). С 1 до 8 \% по региону выросла доля выходцев из семей чиновников. Выходцев из семей военнослужащих и чиновников невысокого чина можно отнести к средним стратам населения региона. Судя по данным персональных дел, судьи, происходившие из чиновничьих и офицерских семей, как правило, не имели недвижимой собственности, и служба была их основным или единственным доходом. В несколько раз выросла доля выходцев из мещан: если в 1890 г. она составляла всего 2 \%, то в 
1913 - 11 \%. Также выросла доля выходцев из крестьян и казаков. Если в 1890 г. их общая доля составляла 1 \%, то в 1913 г. - уже 6 \% (4 \% крестьян и 2 \% казаков). Доля выходцев из низших служащих и специалистов (почтальонов, провизоров, учителей и т.п.) составила к 1913 г. 2 \%. Особенно значительный рост представителей низших и средних страт сельского и городского населения произошел в Волынской губернии. К 1913 г. их совокупная доля среди мировых судей достигла почти трети (17 \% из мещан, по 6 \% из крестьян и казачества, $2 \%$ из низших служащих и специалистов).

Конфессиональный состав корпуса мировых судей представлен в Таблице 2.

Таблица 2. Конфессиональный состав корпуса мировых судей Юго-Западного края в 1890-1913 гг., чел. (Список чинам, 1890; Список чинам, 1900; Список чинам, 1910; Список чинам, 1913)

\begin{tabular}{|c|c|c|c|c|c|c|c|}
\hline Регион & Год & 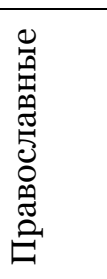 & 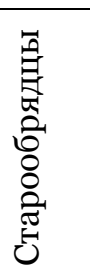 & 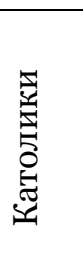 & 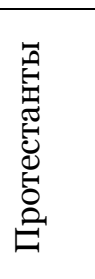 & 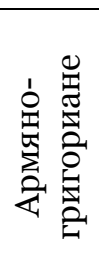 & 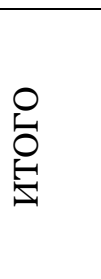 \\
\hline \multirow[t]{4}{*}{ Киевская } & 1890 & 56 & $\mathrm{O}$ & $\mathrm{O}$ & 5 & $\mathrm{O}$ & 61 \\
\hline & 1900 & 63 & O & $\mathrm{O}$ & 3 & 0 & 66 \\
\hline & 1910 & 71 & O & $\mathrm{O}$ & 1 & 0 & 72 \\
\hline & 1913 & 70 & 1 & $\mathrm{O}$ & 0 & 0 & 71 \\
\hline \multirow[t]{4}{*}{ Волынская } & 1890 & 46 & 0 & $\mathrm{O}$ & 1 & 0 & 47 \\
\hline & 1900 & 55 & 1 & $\mathrm{O}$ & 1 & 0 & 57 \\
\hline & 1910 & 53 & 1 & 1 & 1 & 0 & 56 \\
\hline & 1913 & 48 & 1 & 1 & 3 & 0 & 53 \\
\hline \multirow[t]{4}{*}{ Подольская } & 1890 & 55 & O & $\mathrm{O}$ & 0 & 0 & 55 \\
\hline & 1900 & 54 & $\mathrm{O}$ & $\mathrm{O}$ & $\mathrm{O}$ & $\mathrm{O}$ & 54 \\
\hline & 1910 & 46 & O & 2 & 1 & 3 & 52 \\
\hline & 1913 & 49 & 1 & 1 & 2 & 1 & 54 \\
\hline \multirow[t]{4}{*}{ Юго-Западный край в целом } & 1890 & 157 & O & O & 6 & O & 163 \\
\hline & 1900 & 172 & 1 & $\mathrm{O}$ & 4 & 0 & 177 \\
\hline & 1910 & 170 & 1 & 3 & 3 & 3 & 180 \\
\hline & 1913 & 167 & 3 & 2 & 5 & 1 & 178 \\
\hline
\end{tabular}

Подавляющее большинство мировых судей региона были православными. За рассматриваемый период их доля несколько снизилась: с 96 \% в 1890 г. до 94 \% в 1913 гг. Доля старообрядцев выросла до 2 \% (3 человека). В 1910 г. среди мировых судей Юго-Западного края было 3 католика (2 \%). Доля протестантов (лютеран и евангелистов) за рассматриваемый период немного снизилась - с 4 до 3 \% (6 человек в 1890 и 5 в 1913 г.). Представители иудейского вероисповедания мировыми судьями не назначались вовсе.

Приоритет сословной и конфессиональной категоризации в империи, отсутствие в этот период четко выраженной этнической идентичности, отсутствие соответствующих данных затрудняет определение этнического состава судейского корпуса. Полностью отдавая себе отчет в условности этнической категоризации по отношению к рассматриваемому периоду и неизбежности ошибок, тем не менее, мы проанализировали этнической состав корпуса мировых судей региона и представили в Таблице 3 динамику этого показателя. При определении этнической принадлежности использовался ряд сведений: антропонимические данные, религиозная принадлежность, место рождения, сословная приписка к той или иной губернии, место расположения земельной недвижимости, издания по антропонимике и генеалогии (Модзалевский, 1908-1914; Редько, 1966; Унбегаун, 1989).

В целом по региону мы видим значительную и существенно возросшую в 1890-е - 1910-е гг. долю украинцев («малороссов», по терминологии переписи) среди мировых судей. Они составляли около половины судейского корпуса. С 1872 по 1890 г. происходило снижение этой доли, а затем ее существенный рост, в результате которого был превышен изначальный показатель 1872 г., и доля украинцев в первые два десятилетия XX в. превысила половину (к 1910-1913 гг. - 54-55 \%). Обратной была динамика доли русских («великоруссов», по терминологии переписи) в судейском корпусе. Она росла до 1890 г., достигнув почти половины, а затем последовательно снижалась вплоть до $1 / 3$ 
всего состава судей региона в 1910-1913 гг. Особенно значительно доля украинцев выросла в Волынской губернии, достигнув к 1910 г. 63 \%. Рост был существенным и в Киевской губернии. В Подольской этот показатель был ниже (44 \% к 1910 г.).

Таблица 3. Динамика этнического состава корпуса мировых судей Юго-Западного края, \% (Список чинам, 1872; Список чинам, 1880; Список чинам, 1890; Список чинам, 1900; Список чинам, 1910; Список чинам, 1913; РГИА. Ф. 1404. Оп. 517 Лит. «Б». Д. 324; Оп. 522. Д. 1414, 2384; Оп. 523. Д. 823, 2911; Оп. 524. Д. 66, 328, 1270, 2455; Оп. 525. Д. 172; Оп. 529. Д. 13, 137, 168, 181; Оп. 544. Д. 667, 706, 2100, 2662, 2861, 3157, 3223, 3411, 3718, 5002, 5190, 5678, 5814, 6142, 6444, 6546, 7815, 8904, 9119; Оп. 545. Д. 8634, 9549, 9659, 9830a, 10089, 10351, 10830, 11131, 12111, 12421, 12471, 14313, 14061; 14607, $14851,14933,14969,15676)$.

\begin{tabular}{|c|c|c|c|c|c|c|c|c|c|}
\hline Губернии и край в целом & Год & 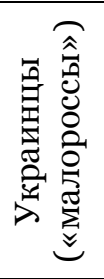 & 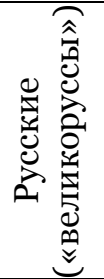 & 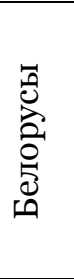 & 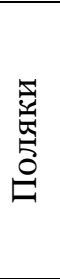 & $\begin{array}{l}\text { 昜 } \\
\text { 焉 }\end{array}$ & 荧 & 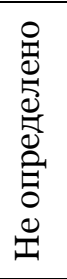 & $\begin{array}{l}0 \\
0 \\
0 \\
0 \\
\end{array}$ \\
\hline \multirow[t]{6}{*}{ Киевская } & 1872 & 46 & 46 & 3 & 0 & 3 & 2 & 0 & 100 \\
\hline & 1880 & 49 & 37 & 3 & o & 5 & 3 & 2 & 100 \\
\hline & 1890 & 44 & 36 & 11 & 0 & 8 & 0 & 0 & 100 \\
\hline & 1900 & 50 & 35 & 8 & o & 5 & 0 & 3 & 100 \\
\hline & 1910 & 54 & 33 & 10 & 0 & 1 & 0 & 1 & 100 \\
\hline & 1913 & 59 & 25 & 13 & 0 & 0 & 0 & 3 & 100 \\
\hline \multirow[t]{6}{*}{ Волынская } & 1872 & 47 & 43 & 4 & 0 & 0 & 0 & 6 & 100 \\
\hline & 1880 & 40 & 51 & 2 & 2 & o & O & 4 & 100 \\
\hline & 1890 & 43 & 49 & 4 & 0 & 2 & 0 & 2 & 100 \\
\hline & 1900 & 58 & 33 & 2 & $\mathrm{O}$ & 2 & $\mathrm{O}$ & 5 & 100 \\
\hline & 1910 & 63 & 27 & 4 & 2 & 2 & 0 & 4 & 100 \\
\hline & 1913 & 60 & 30 & 2 & 2 & 4 & 0 & 2 & 100 \\
\hline \multirow[t]{6}{*}{ Подольская } & 1872 & 47 & 36 & o & 0 & 8 & 2 & 8 & 100 \\
\hline & 1880 & 37 & 45 & 4 & o & 8 & $\mathrm{O}$ & 6 & 100 \\
\hline & 1890 & 33 & 56 & $\mathrm{O}$ & 0 & 4 & 2 & 5 & 100 \\
\hline & 1900 & 41 & 46 & o & 0 & 2 & $\mathrm{O}$ & 11 & 100 \\
\hline & 1910 & 44 & 42 & 2 & 2 & 2 & 6 & 2 & 100 \\
\hline & 1913 & 44 & 43 & 4 & 2 & $\mathrm{O}$ & 4 & 4 & 100 \\
\hline \multirow{6}{*}{$\begin{array}{c}\text { Юго-Западный край в } \\
\text { целом }\end{array}$} & 1872 & 47 & 42 & 2 & 0 & 4 & 1 & 4 & 100 \\
\hline & 1880 & 43 & 44 & 3 & 1 & 4 & 1 & 4 & 100 \\
\hline & 1890 & 40 & 47 & 6 & o & 5 & 1 & 2 & 100 \\
\hline & 1900 & 50 & 38 & 3 & 0 & 3 & 0 & 6 & 100 \\
\hline & 1910 & 54 & 34 & 6 & 1 & 2 & 2 & 2 & 100 \\
\hline & 1913 & 55 & 32 & 7 & 1 & 1 & 1 & 3 & 100 \\
\hline
\end{tabular}

Сопоставим представительство основных по численности этнических групп региона в корпусе мировых судей (данные за 1900 г.) и в сфере управления в целом (администрация, суд, полиция, по данным переписи 1897 г.). Используем при этом сопоставлении индекс представительства (Таблица 4).

В целом по Юго-Западному краю уровень представительства украинцев и русских в корпусе мировых судей был близок к уровню их представительства в управлении в целом (что косвенно подтверждают и оценки этнического состава корпуса мировых судей). На губернском уровне более значимые различия наблюдаются только по Волынской губернии. Здесь представительство украинцев среди мировых судей близко к пропорциональному (то есть доля украинцев среди мировых судей близка к их доле среди всех занятых) и существенно, почти в два раза, выше их представительства в сфере управления в целом. Евреи совсем не представлены среди мировых судей и очень слабо в управлении в 
целом. Поляки очень слабо представлены в корпусе мировых судей, но пропорционально и выше уровня пропорциональности - в сфере управления в целом. На основании Таблицы 4 можно констатировать, что «украинизация» корпуса мировых судей несколько опережала этот процесс в управлении в целом. Уровень представительства украинцев среди мировых судей по региону в целом оставался ниже пропорционального примерно на треть, но на Волыни приближался к пропорциональному.

Таблица 4. Индекс представительства этнических групп губерний Юго-Западного края в корпусе мировых судей (1900 г.) и сфере управления (администрация, суд, полиция, 1897 г.) в целом (Первая Всеобщая перепись. Т. 16, 1904: 168-169, 178-183; Первая Всеобщая перепись. Т. 8, 1904: 154-155, 164171; Первая Всеобщая перепись. Т. 32, 1904: 164-165, 174-177)

\begin{tabular}{|c|c|c|c|c|c|c|c|c|c|c|c|c|}
\hline & \multicolumn{2}{|c|}{ Украинцы } & \multicolumn{2}{|c|}{ Русские } & \multicolumn{2}{|c|}{ Евреи } & \multicolumn{2}{|c|}{ Белорусы } & \multicolumn{2}{|c|}{ Поляки } & \multicolumn{2}{|c|}{ Немцы } \\
\hline & Мир. & Упр. & Мир. & Упр. & Мир. & Упр. & Мир. & Упр. & Мир. & Упр. & Мир. & Упр. \\
\hline Киевская & 0,7 & 0,7 & 3,0 & 4,0 & 0,0 & 0,1 & 15,3 & 2,2 & 0,0 & 1,0 & 7,8 & 1,1 \\
\hline Волынская & 0,9 & 0,5 & 4,6 & 8,0 & 0,0 & 0,1 & 9,8 & 3,2 & 0,0 & 1,3 & 0,3 & 0,1 \\
\hline Подольская & 0,5 & 0,6 & 77 & 7,9 & 0,0 & 0,1 & 0,0 & 4.7 & 0,0 & 1,8 & 8,8 & 0,8 \\
\hline $\begin{array}{c}\text { Юго-Западный } \\
\text { край в целом }\end{array}$ & 0,7 & 0,6 & 4,4 & 5,8 & 0,0 & 0,1 & 12,5 & 2,7 & 0,0 & 1,3 & 1,4 & 0,2 \\
\hline
\end{tabular}

Сопоставим долю украинцев и русских среди мировых судей за 1900 г. с их долей среди всего населения, городского населения и лиц, имеющих образование выше начального за 1897 г. (по данным всеобщей переписи). Это сопоставление, представленное в таблице 5, показывает, что представительство украинцев в мировом судейском корпусе было ниже, чем их представительство во всем населении (50 и 77\% соответственно), но при этом в два раза выше, чем их представительство среди городского населения, в три раза выше, чем среди лиц с образованием выше начального.

Таблица 5. Соотношение украинцев и русских среди мировых судей (1900 г.), всего населения, горожан, а также лиц, получивших образование выше начального (1897 г.) в губерниях ЮгоЗападного края, \% (источники данных - см. таблицы 1, 3, 4)

\begin{tabular}{|l|c|c|c|c|c|c|c|c|}
\hline & \multicolumn{2}{|c|}{ Мировые судьи } & \multicolumn{2}{c|}{ Все население } & \multicolumn{2}{c|}{$\begin{array}{c}\text { Городское } \\
\text { население }\end{array}$} & \multicolumn{2}{c|}{$\begin{array}{c}\text { Лица с } \\
\text { образованием выше } \\
\text { начального }\end{array}$} \\
\hline & Укр. & Рус. & Укр. & Рус. & Укр. & Рус. & Укр. & Рус. \\
\hline Киевская & 50 & 35 & 79 & 6 & 28 & 33 & 15 & 59 \\
\hline Волынская & 58 & 33 & 70 & 4 & 20 & 19 & 18 & 52 \\
\hline Подольская & 41 & 46 & 81 & 3 & 19 & 14 & 18 & 53 \\
\hline $\begin{array}{l}\text { Юго-Западный } \\
\text { край в целом }\end{array}$ & 50 & 38 & 77 & 4 & 24 & 25 & 16 & 56 \\
\hline
\end{tabular}

Полное недопущение евреев (иудеев) к судейским должностям и ограничения в отношении поляков (католиков) было целенаправленной политикой правительства в западных губерниях (Кузьмин, 2018). Но это не означало полного отсутствия их представительства в том или ином качестве в мировом судопроизводстве в целом. Они участвовали в качестве частных и присяжных поверенных (адвокатов), а поляки, кроме того, и почетных мировых судей. На данный момент у нас нет полных данных по количеству и доле католиков среди почетных мировых судей. Представим некоторые предварительные сведения по этому вопросу.

Мировые съезды своим коллегиальным решением выбирали и представляли в министерство на утверждение кандидатуры почетных мировых судей. Нередко потенциальные кандидаты сами ходатайствовали перед съездом о назначении почетным судьей. По данным по мировым округам Киевской губернии 1913 г., на последующий трехгодичный цикл на должность почетных мировых судей было выдвинуто 11 католиков из общего количества 223 кандидатов. Все кандидаты-католики были утверждены министром. Мотивируя выбор кандидатами братьев Ржевуских, Сквирский мировой съезд отмечал, что они «по высоконравственным качествам своим и знанию местных условий являются весьма желательными кандидатами на должность почетного мирового судьи» (РГИА. Ф. 1405. Оп. 545. Д. 17140: 31-43об.).

О стремлении поляков-католиков получить статус почетного мирового судьи и участвовать в мировых съездах имеются сведения также из губерний Северо-Западного края. Активно участвуя в мировом суде, утверждал корреспондент «Руси», «поляки получают известную долю политической власти» в крае (П.П., 1883). В Юго-Западном крае также видны эти тенденции, хотя и в меньшей степени. 
Почетные мировые судьи из числа поляков иногда приобретали значительное влияние в судебном округе. Так, в 1905 г. министру юстиции от группы жителей Бердичева поступила жалоба на участкового мирового судью Бердичевского округа Д.Ф. Подоляку и действовавшего с ним «в сговоре» почетного мирового судью поляка-католика В.Е. Каменского. В жалобе указывалось, что Каменский «состоит прямо на жаловании у местных польских помещиков и, участвуя противозаконно в роли председательствующего, что ему прямо воспрещено Сенатом, всегда разрешает дела в пользу поляков, если участвует в деле». Старший председатель Киевской судебной палаты, собрав сведения о деятельности Каменского, не согласился с жалобщиками и сделал вывод о том, что тот «пользуется среди разноплеменного населения г. Бердичева всеобщим уважением». Из материалов дела трудно сделать окончательный вывод о том, была ли в действительности со стороны Каменского тенденциозность в защите интересов польских участников процессов. Но несомненна большая активность и вовлеченность представителя польского сообщества в дела мировой юстиции (РГИА. Ф. 1405. Оп. 545. Д. 10351).

И. Захарьин в воспоминаниях о своей службе в качестве мирового судьи в начале 1880-х гг. в Литинском уезде Подольской губернии дал яркий образ почетного мирового судьи Килькевича, выходца из местной польской шляхты. Он имел университетское образование и активно участвовал в заседаниях мирового съезда, рассчитывая получить место участкового судьи. Захарьин, который за несколько лет службы хорошо изучил местный социальный и национальный контекст, установил отношения с представителями и польской, и еврейской общин, полагал, что устранение поляков от службы участковыми мировыми судьями наносило вред делу правосудия в регионе. В качестве участковых судей они бы сочетали необходимое для этой должности профессиональное образование с хорошим знанием местности и «различных национальностей - евреев, шляхты и крестьян, - которые населяли собой этот богатейший в России край» (Захарьин, 1900: 94-98, 356-360).

Некоторые мировые судьи православного вероисповедания были связаны с местным католическим обществом тесным общением и родственно-брачными связями. В 1890 г. в ЮгоЗападном крае было по меньшей мере 9 таких судей. Вероятно, часть из них и сами были польского происхождения. Так, мировой судья Каневского уезда (по данным на 1890 г.) В.А. Колусовский, выходец из мещан, был женат на дворянке-католичке. В одной из жалоб на действия этого судьи он был назван поляком, тесно связанным с другими представителями польского сообщества (РГИА. Ф. 1405. ОП. 544. Д. 6142).

В 1903 г. в Министерство юстиции поступила жалоба от группы жителей, крестьян и мещан Владимирволынского уезда Волынской губернии (судя по антропонимике, украинцев и евреев), на мирового судью А.Г. Кранца. В жалобе, в частности, указывалось, что движение большинства судебных дел в участке этого судьи контролировалось письмоводителем мирового судьи Г. Соболевским и частным поверенным Ю. Древновским - двоюродными братьями польского происхождения. Жалобщики отмечали, что «правосудие и все человечество 3 мирового участка Владимирволынского округа состоит в полном распоряжении Соболевского..., вместо одного Кранца имеются в действительности два других мировых судьи - Соболевский и Древновский» (РГИА. Ф. 1405. ОП. 544. Д. 6546).

Мировые съезды своим коллегиальным решением выбирали частных поверенных (адвокатов). Нередко они учитывали этноконфессиональную принадлежность кандидатов. Так, по данным ревизии 1895 г., при Новоградволынском мировом съезде Волынской губернии числилось семь частных поверенных - шесть поляков-католиков и один православный. При этом, отмечал ревизор, съезд «принципиально держится недопущения евреев в число частных поверенных» (РГИА. Ф. 1405. Оп. 515. Д. 70: 43). Но при многих других мировых судебных округах региона в качестве частных поверенных состояло значительное количество представителей еврейского населения. Так, по данным ревизии 1895 г. мировых округов Волынской губернии, в Житомирском округе 12 из 19 частных поверенных при мировом съезде были евреями, в Овручском - 2 из 4 (РГИА. Ф. 1405. Оп. 515. Д. 70: 9-90б., 72). По данным за 1906 г. по Черкасскому округу Киевской губ., представители еврейского населения составляли более половины корпуса частных поверенных при мировом съезде (РГИА. Ф. 1405. Оп. 545. Д. 17235: 249-309). И. Захарьин особо подчеркивал активное и позитивное для дела правосудия участие поляков в частной адвокатуре при мировой юстиции Юго-Западного края (Захарьин, 1900: 127-135).

В Таблице 6 сопоставлены индексы представительства основных этнических групп региона в сфере частной юридической деятельности (по данным переписи 1897 г.) с индексами их представительства в корпусе мировых судей (за 1900 г.). Как видим, поляки и евреи, слабо или вовсе не представленные в корпусе мировых судей, отчасти компенсировали это ярко выраженным, выше пропорционального уровня, представительством в сфере частной юридической деятельности. Уровень представительства поляков в частной юридической сфере в несколько раз превышал пропорциональный. 
Таблица 6. Индекс представительства этнических групп губерний Юго-Западного края в корпусе мировых судей (1900 г.) и сфере частной юридической деятельности (1897 г.) (источники данных см. Таблицу 4)

\begin{tabular}{|c|c|c|c|c|c|c|c|c|c|c|c|c|}
\hline & \multicolumn{2}{|c|}{ Украинцы } & \multicolumn{2}{|c|}{ Русские } & \multicolumn{2}{|c|}{ Евреи } & \multicolumn{2}{|c|}{ Белорусы } & \multicolumn{2}{|c|}{ Поляки } & \multicolumn{2}{|c|}{ Немцы } \\
\hline & Мир.* & ЧЮ** & Мир. & ЧЮ & Мир. & ЧЮ & Мир. & ЧЮ & Мир. & ЧЮ & Мир. & ЧЮ \\
\hline Киевская & 0,7 & 0,2 & 3,0 & 3,9 & $\mathrm{O}, \mathrm{O}$ & 1,1 & 15,3 & 0,4 & $\mathrm{O}, \mathrm{O}$ & 8,0 & 7,8 & 0,7 \\
\hline Волынская & 0,9 & 0,1 & 4,6 & 4,2 & $\mathrm{O}, \mathrm{O}$ & 1,8 & 9,8 & 7,5 & 0,0 & 4,2 & 0,3 & 0,1 \\
\hline Подольская & 0,5 & 0,1 & 7,7 & 5,8 & 0,0 & 2,3 & 0,0 & O & 0,0 & 7,2 & 8,8 & 2,2 \\
\hline $\begin{array}{c}\text { Юго- } \\
\text { Западный } \\
\text { край }\end{array}$ & 0,7 & 0,1 & 4,4 & 4,5 & 0,0 & 1,6 & 12,5 & 1,8 & 0,0 & 5,9 & 1,4 & 0,2 \\
\hline
\end{tabular}

*Мир. - корпус мировых судей; **ЧЮ - занятые в сфере частной юридической деятельности.

Процессы профессионализации корпуса мировых судей Юго-Западного края наглядно отражают данные, приведенные в Таблице 7.

Таблица 7. Динамика состава корпуса мировых судей Юго-Западного края по критерию полученного образования, \% (источники данных - см. Таблицы 1, 2)

\begin{tabular}{|c|c|c|c|c|c|c|c|c|c|c|c|c|c|}
\hline \multirow[t]{2}{*}{$\begin{array}{l}\text { Губернии и } \\
\text { Край в } \\
\text { целом }\end{array}$} & \multirow[t]{2}{*}{ Год } & \multicolumn{4}{|c|}{$\begin{array}{c}\text { Высшее юридическое } \\
\text { Образование в } \\
\text { университетах региона } \\
\text { (Юго-Западный край, } \\
\text { Малороссия, Слободская } \\
\text { Украина, Новороссия) }\end{array}$} & \multirow{2}{*}{ 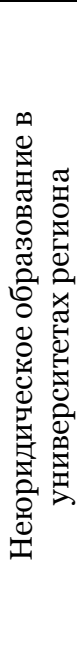 } & \multirow{2}{*}{ 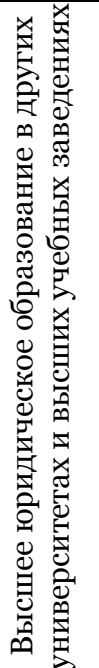 } & \multicolumn{4}{|c|}{$\begin{array}{c}\text { Начальное, среднее и высшее } \\
\text { Образование в учебных } \\
\text { заведениях неюридического } \\
\text { профиля }\end{array}$} & \multirow{2}{*}{ 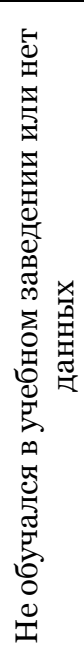 } & \multirow{2}{*}{ 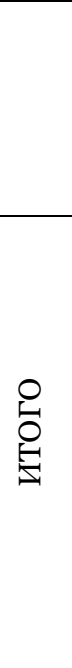 } \\
\hline & & 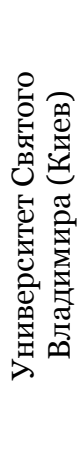 & 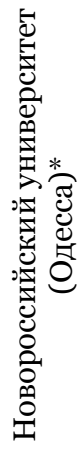 & 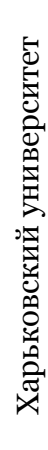 & 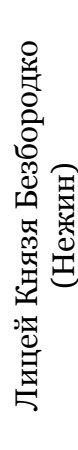 & & & 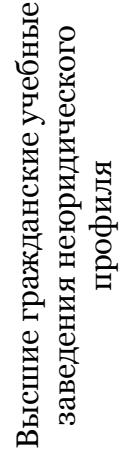 & 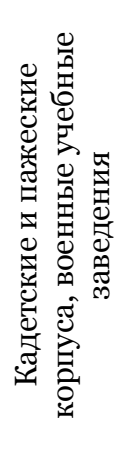 & 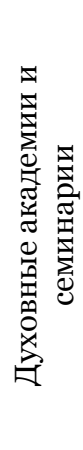 & 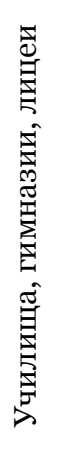 & & \\
\hline I & II & III & IV & T & VI & VII & VIII & IX & $\mathrm{X}$ & XI & XII & XIII & XIV \\
\hline \multirow[t]{6}{*}{ Киевская } & 1872 & 29 & 5 & 7 & 7 & O & 17 & 3 & 12 & O & 14 & 7 & 100 \\
\hline & 1880 & 24 & 7 & 5 & 7 & O & 24 & 3 & 15 & O & 12 & 3 & 100 \\
\hline & 1890 & 25 & 7 & 2 & 13 & 5 & 30 & 5 & 7 & 2 & 5 & 2 & 100 \\
\hline & 1900 & 52 & 3 & 2 & 3 & 3 & 26 & O & 5 & O & 8 & O & 100 \\
\hline & 1910 & 65 & 4 & 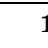 & 3 & 0 & 21 & 3 & O & O & 3 & $\mathrm{O}$ & 100 \\
\hline & 1913 & 65 & 7 & 3 & 1 & O & 17 & 1 & O & 1 & 4 & O & 100 \\
\hline \multirow[t]{6}{*}{ Волынская } & 1872 & 24 & 6 & $\varepsilon$ & 4 & $\mathrm{O}$ & 16 & 4 & 14 & 6 & 8 & 8 & 100 \\
\hline & 1880 & 21 & 4 & 6 & 4 & 0 & 38 & 2 & 4 & 4 & 9 & 6 & 100 \\
\hline & 1890 & 17 & 6 & 4 & 11 & 2 & 23 & 4 & 11 & 11 & 11 & $\mathrm{O}$ & 100 \\
\hline & 1900 & 39 & 2 & 5 & 7 & O & 28 & 4 & 4 & 5 & 7 & O & 100 \\
\hline & 1910 & 70 & 0 & 5 & 2 & O & 14 & O & 2 & 2 & 5 & O & 100 \\
\hline & 1913 & 74 & 2 & 4 & $\mathrm{O}$ & 0 & 13 & $\mathrm{O}$ & 2 & 2 & 4 & $\mathrm{O}$ & 100 \\
\hline \multirow[t]{4}{*}{ Подольская } & 1872 & 21 & 6 & 4 & 13 & O & 30 & O & 13 & 6 & 6 & 2 & 100 \\
\hline & 1880 & 20 & 2 & 2 & 4 & O & 43 & 2 & 10 & 10 & 8 & 0 & 100 \\
\hline & 1890 & 16 & 7 & 4 & 11 & 2 & 36 & 7 & 7 & 7 & 2 & O & 100 \\
\hline & 1900 & 24 & 19 & c & 4 & 2 & 35 & 0 & 4 & 2 & 2 & 0 & 100 \\
\hline
\end{tabular}




\begin{tabular}{|c|c|c|c|c|c|c|c|c|c|c|c|c|c|}
\hline & 1910 & 25 & 27 & 4 & 4 & 0 & 38 & $\mathrm{O}$ & 0 & 2 & $\mathrm{O}$ & 0 & 100 \\
\hline & 1913 & 22 & 35 & 2 & 0 & O & 41 & O & 0 & O & 0 & 0 & 100 \\
\hline \multirow{6}{*}{$\begin{array}{l}\text { Юго- } \\
\text { Западный } \\
\text { край в } \\
\text { целом }\end{array}$} & 1872 & 25 & 6 & 6 & 8 & 0 & 21 & 2 & 13 & 4 & 9 & 6 & 100 \\
\hline & 1880 & 22 & 4 & 4 & 5 & 0 & 34 & 3 & 10 & 4 & 10 & 3 & 100 \\
\hline & 1890 & 20 & 7 & 3 & 12 & 3 & 30 & 6 & 8 & 6 & 6 & 1 & 100 \\
\hline & 1900 & 39 & 7 & 5 & 5 & 2 & 29 & 1 & 4 & 2 & 5 & 0 & 100 \\
\hline & 1910 & 55 & 9 & 3 & 3 & 0 & 24 & 1 & 1 & 1 & 3 & 0 & 100 \\
\hline & 1913 & 54 & 14 & 3 & 1 & 0 & 23 & 1 & 1 & 1 & 3 & 0 & 100 \\
\hline
\end{tabular}

* Включая Ришельевский лицей, на базе которого в 1865 г. создан Императорский Новороссийский университет (Одесса).

В период с 1872 по 1913 гг. доля лиц с высшим юридическим образованием (сумма данных в колонках III-VI и VIII таблицы 7) среди мировых судей Юго-Западного края выросла с 66 до 95 \%. При этом юридическое образование в учебных заведениях украинских регионов (университеты в Киеве, Одессе, Харькове и лицей в Нежине) в 1872 г. получили 51 \%, а в 1913 г. - 72 \% мировых судей Юго-Западного края. В Киевской губернии эта доля выросла с 48 до 76 \%, Волынской - с 42 до 80 \%, в Подольской - с 44 до $59 \%$.

Более чем в два раза за этот период выросла среди мировых судей Юго-Западного края доля выпускников юридического факультета Киевского университета Св. Владимира (колонка III) - с 25 до $54 \%$. В Киевской и Волынской губерниях, входящих в округ Киевской судебной палаты, доля выпускников этого университета среди мировых судей выросла более чем в 2 и 3 раза соответственно: с 29 до 65 \% и с 24 до 74 \%. В Подольской губернии, которая входила в округ Одесской судебной палаты, доля среди мировых судей выпускников юридического факультета Новороссийского университета в Одессе (колонка IV) выросла с 6 до 35 \%. Доля выпускников юридического факультета Св. Владимира оставалась здесь достаточно высокой и относительно неизменной - 21 и 22 \% соответственно.

Оставалась относительно стабильной (в 1872 г. - 21 \%, в 1913 - 23 \%) общая доля мировых судей Юго-Западного края, получивших юридическое образование в высших учебных заведениях других регионов империи (Московский, Санкт-Петербургский, Казанский и др. университеты, Демидовский юридический лицей и др.). Выявленное существенное увеличение в Юго-Западном крае доли выпускников юридических факультетов университетов Киева и Одессы происходило не столько за счет доли выпускников юридических факультетов других университетов, сколько за счет уменьшения доли среди мировых судей лиц, не имевших высшего юридического или иного высшего образования.

Изучение конкретных судейских карьер наглядно показывает действие институциональных механизмов, которые приводили к регионализации профессиональных кадров мировой юстиции. После окончания юридических факультетов Киевского или Одесского университетов дипломированные выпускники получали, как правило, должность кандидата на судейские места при судебных палатах, окружных судах и мировых съездах Киевского или Одесского судебных округов. В течение нескольких лет кандидаты командировались на короткие сроки на разные должности секретарей и их помощников при департаментах и судах, судебных следователей, нотариусов и пр. Переход с должности на должность происходил в рамках судебных округов. Тем самым будущие мировые судьи знакомились одновременно и со спецификой судебно-юридической работы, и с особенностями населения региона. После успешного прохождения этой практики кандидаты объявлялись готовыми для самостоятельной судейской работы и отправлялись в тот или иной мировой округ для замещения вакансий. В дальнейшем перемещения между отдельными мировыми округами происходили, как правило, также в рамках соответствующих округов судебных палат Киевской и Одесской. Контроль над назначением судей осуществлял преимущественно старший председатель судебной палаты. Все это способствовало пополнению, циркуляции и стабилизации мирового судейского корпуса преимущественно в рамках региона.

Для иллюстрации выявленных тенденций приведем несколько примеров конкретных судебных карьер мировых судей, выходцев в основном из низших сословий.

Дмитрий Федорович Подоляка, родившийся в 1846 г., происходил из малороссийских казаков. После окончания в 1872 г. университета Св. Владимира он в течение четырех лет работал на разных временных позициях при Киевской судебной палате. Характерно, что в 1874 г. Подоляка отказался от предложенной ему министерством должности мирового судьи в Кутаисской губернии, предпочтя оставаться на более низкой позиции в своем регионе. В 1876 г. он ходатайствовал о назначении его мировым судьей в Киевской губернии, «вблизи моей родины». Киевский прокурор поддержал ходатайство, полагая, что «назначение его мировым судьей Западного края может быть сделано с несомненной пользой». В 1876 г. Подоляка был назначен участковым мировым судьей в Радомысльском уезде Киевской губернии. На этой должности он проработал 20 лет, в 1896 г. был переведен на аналогичную позицию в Бердичевский уезд Киевской губернии. В 1905 г. уже очень

$$
-1843-
$$


опытный судья Подоляка был повышен в статусе, получив место председателя Бердичевского съезда мировых судей. В 1906 г. он был переведен в Житомирский уезд Волынской губернии, где до 1913 г. исполнял обязанности участкового мирового судьи и председателя съезда. В 1914 г. он был вновь переведен в Киевскую губернию, где в течение года прослужил в должности председателя мирового съезда. После увольнения в 1914 г. в отставку по возрасту он получил статус почетного мирового судьи в Радомысльском уезде - там, где начинал свою судейскую карьеру (РГИА. Ф. 1405. Оп. 545. Д. 10351).

Сергей Антонович Храновский, родившийся в 1875 г. и происходивший из крестьян Балтского уезда Подольской губернии, в 1899 г. закончил юридический факультет университета Св. Владимира в Киеве, после окончания университета должность кандидата на судебные должности, Храновский в течение 5 лет назначался на короткие сроки на различные низшие служебные позиции при Одесской судебной палате. В 1904 г. он был мировым судьей в своем родном Балтском округе, где и прослужил до революции 1917 г. При этом назначение судьей непосредственно в своей родной местности имело в случае Храновского определенные негативные последствия. Он был обвинен несколькими местными жителями в тенденциозности при вынесении решений в пользу своих родственников (РГИА. Ф. 1405. Оп. 545. Д. 14313).

Филипп Антонович Прокопович родился в 1874 г. в Житомире в семье мещанина. После окончания в 1898 г. юридического факультета университета Св. Владимира он 6 лет работал на разных низших должностях при Киевской судебной палате и окружном суде. Пройдя необходимую практическую подготовку, в 1905 г. Прокопович получил постоянное место мирового судьи в ЗаславоОстрожском мировом округе в Волынской губернии. В 1911 г. Прокопович ходатайствовал перед министерством о назначении членом окружного суда. Прокурор Киевской судебной палаты дал ему положительную характеристику, отметив, что Прокопович - один из выдающихся мировых судей, отличающийся отличным знанием законов и сенатской практики, умением быстро разбираться в судебном материале. Его приговоры «лишены политической окраски». Отмечалось также, что Прокопович - «примерный семьянин, верный сын православной церкви, чужд полонофильских тенденций, состоит братчиком-хозяином и членом совета Острожского Свято-КириллоМефодиевского православного братства, жена и родственники все православные, досуг проводит за чтением статей юридического содержания и научных сочинений». Тем не менее просимой вакансии не было, и Прокопович вплоть до революции прослужил в том же мировом округе участковым мировым судьей (РГИА. Ф. 1405. Оп. 545. Д. 10830).

Николай Дмитриевич Шахнюк, происходящий из крестьян Острожского уезда Волынской губернии, в 1896 г. окончил юридический факультет университета Св. Владимира. Прослужив несколько лет на временных низших должностях при Киевской судебной палате и Киевском окружном суде, в 1903 он стал мировым судьей в Черкасском уезде Киевской губернии, где и служил до конца имперского периода (РГИА. Ф. 1405. Оп. 545. Д. 14851).

Выходец из крестьян Житомирского уезда Варфоломей Иванович Пухкий, хотя высшее юридическое образование получил в Санкт-Петербургском университете, его судебная карьера проходила в родной губернии. После нескольких лет службы при судебной палате и окружном суде в Киеве он в 1909 г. получил должность мирового судьи в Овручском уезде Волынской губернии, которую и занимал до конца империи (РГИА. Ф. 1405. Оп. 524. Д. 2455).

Характерно, что судьи рассматриваемого региона, желая сменить по личным или служебным основаниям мировой округ или получить повышение в виде должности члена окружного суда, ходатайствовали перед министерством, как правило, о назначении в географических рамках югозападных, малороссийских или новороссийских губерний. От предложений со стороны министерства о переводе в другие регионы империи они обычно отказывались (РГИА. Ф. 1405. Оп. 522. Д. 1414; РГИА. Ф. 1405. Оп. 544. Д. 3157; РГИА. Ф. 1405. Оп. 545. Д. 12471; РГИА. Ф. 1405. Оп. 545. Д. 15676).

Среди судей местного происхождения - украинцев - выделялись люди «старой закалки». Основным преимуществом этой категории судей было не столько строгое знание законов и юридической техники, сколько прекрасное знакомство с местным населением, по большей части украинским. Нередко они не имели специального юридического образования (Качиони, 1916: 222-225). Но доля таких судейнепрофессионалов патриархального типа из числа региональной дворянской элиты постепенно уменьшалась. Статистические данные и приведенные примеры служебных карьер характеризует постепенно растущий поток судейских кадров нового поколения - выходцев из средних и низших сословий украинских губерний, украинцев по происхождению, получивших профессиональное юридическое образование в университетах региона (реже - в других). Обладая юридическими знаниями, они в то же время, как уроженцы украинских губерний, не испытывали проблем с языковым барьером, хорошо знали местные хозяйственные и социальные условия и обычаи.

Одновременно идущие процессы профессионализации, демократизации и коренизации мировой юстиции выражались, в частности, в росте ее востребованности широкими массами населения. В таблице 8 отражен рост количества обращений с гражданскими исками (количество исков в расчете на 1 тыс. человек) в мировые суды юго-западных губерний. 
Таблица 8. Динамика количества поступивших в мировые суды юго-западных губерний гражданских дел (1885-1913 гг.), на тыс. чел. (Верняев, 2021: 101-104)

\begin{tabular}{|l|c|c|c|c|}
\hline Губерния & 1885 год & 1897 год & 1909 год & 1913 год \\
\hline Киевская & 13,1 & 16,7 & 24,5 & 28,9 \\
\hline Волынская & 14,1 & 14,5 & 18,4 & 20,2 \\
\hline Подольская & 11,5 & 13,0 & 15,4 & 17,2 \\
\hline
\end{tabular}

За полтора десятилетия - с 1897 по 1913 гг. - прирост судебной активности в части гражданских исков в расчете на 1 тыс. чел. в юго-западных губерниях составил 45 \% (в Киевской губернии - 73 \%, в Волынской - 39,3 \%, в Подольской - 32,3\%). При этом прирост доли городского населения за этот же период составил в юго-западных губерниях в целом 10,4 \% (с 9,6 \% в 1897 г. до 10,6 \% в 1913 г.) (Верняев, 2021: 105). Опережающий прирост судебной активности в сравнении с приростом доли городского населения может свидетельствовать о все большем обращении в мировые суды с гражданскими исками сельского населения. Подтверждение этому находим как в оценочных суждениях судебных деятелей и судебной периодики того времени, так и в материалах ревизий судебного ведомства. Осуществленные в 1895 г. в специальных юридических и общих изданиях анализ результатов 25-летней деятельности мировой юстиции в Западном крае и ревизия ее текущей работы показали существенные достижения. Констатировалось, что среди других пореформенных судебных учреждений мировой суд занимает «почетное положение» как «близкий к народу защитник правды». Отмечалось, что редко встретишь «такую лояльность простого народа и подчинение суду, как здесь, и обратно - недоверие к другим составам власти». Обращалось внимание на то, что мировые судьи здесь назначаются из лиц с высшим юридическим образованием, профессионально подготовленных для службы в судебном ведомстве. Они, как правило, по многу лет служили в своем участке - соответственно были хорошо знакомы с местными условиями (Верняев, 2021: 106-108).

По данным проверки деятельности мировых судов Волынской губ. в 1895 г., ревизор Меркулов отмечал, что в ряде местностей именно судебная власть являлась основной и при этом очень востребованной. Особенно это относилось к тем сельским территориям (как, например, в Овручском уезде), где находились многочисленные поселения мещан, которые занимались сельским хозяйством и владели землей на праве частной собственности, принадлежавшей при этом «не отдельным лицам, а целым обществам». Поскольку это были мещане, у них, в отличие от крестьян, не было своего сословного суда, и огромное количество споров разрешалось в мировом суде. Особенно много исков было по поземельным вопросам: «сервитуты, общая толока, лесные покосы крестьян среди помещичьего леса, закрепление по документам права собственности одной из сторон без указания в натуре, где и что принадлежит одному, а где - другому - все это вызывает частые споры, правонарушения, а иногда и прискорбные столкновения». Мировая юстиция была также особенно востребована у такой многочисленной на Волыни категории крестьян, как чиншевики. Кроме того, отмечал ревизор, многочисленные в Волынской губернии европейские колонисты - «чехи и немцы в числе более 120 тыс. душ, пришедшие сюда со своим жизненным укладом», - также давали немало судебных дел мировой юстиции.

По наблюдению ревизора Меркулова, население обращалось к мировому судье даже с самыми мелкими исками и жалобами: «Так, встречались дела, в которых истец обращался к судье о взыскании с ответчика 70-80 копеек; немало дел у судей, которые по ценности не превышают 10 рублей, самые ничтожные проступки побуждают население обращаться к судье и искать у него защиты от правонарушений». Для крестьян общегражданский мировой суд нередко был привлекательнее своего волостного: «Замечено, что крестьяне иногда определяют цену иска более 100 руб. для того только, чтобы их разбирал не волостной суд, а мировой судья». Состоятельные люди также находили возможность манипулировать подсудностью, переводя ее из окружного суда в мировой. Ревизор отмечает активность не только тяжущихся, но и свидетелей: «...ромадное большинство дел мировых установлений, как уголовных, так и гражданских, разрешается на основании свидетельских показаний; свидетели охотно являются на суд, иногда по несколько раз, не возбуждая вопроса о вознаграждении их за путевые издержки и отвлечение от занятий, хотя нередки случаи явки их в камеру судьи из таких местностей, расстояние коих давало бы им по закону право на вознаграждение». Благоприятные отзывы о мировом суде были получены от представителей разных категорий населения. По итогам проверки ревизор резюмировал, что «быть на Волыни судьей далеко не легко, и тем не менее ближайшее знакомство мое с рассмотренными мною судебно-мировыми округами привело меня к выводу, что мировой институт в здешней местности в общем исполняет возложенную на него функцию добросовестно, что население не только к нему привыкло, но относится с подлежащим доверием и уважением и в случае даже ничтожного правонарушения ищет иногда защиты своих прав у мировых судей» (РГИА. Ф. 1405. Оп. 515. Д. 70: 1-20б.). 


\section{5. Заключение}

Состав корпуса мировых судей в Юго-Западном крае существенно демократизировался: доля элитных сословных страт существенно сократилась, увеличилась доля представителей средних и низших слоев. К 1913 г. около четверти всех мировых судей были выходцами из крестьян, мещан, казаков, низших служащих и т.п. Расширение доступа в университеты, получение высшего юридического образования позволяли представителям этих слоев общества во все большем числе претендовать на должности мировых судей и получать их.

К концу империи корпус мировых судей стал почти полностью профессиональным, вакансии заполнялись почти исключительно лицами с высшим юридическим образованием. При этом выявлена яркая тенденция регионализации профессиональных кадров мировой юстиции. Во все большей степени этот судейский корпус заполняли профессионалы-юристы, закончившие основные региональные высшие учебные заведения региона, прежде всего Киевский университет Св. Владимира и в меньшей степени одесский Новороссийский университет (был значим, главным образом, для Подольской губернии).

Исследование динамики этнического состава корпуса мировых судей показало, что до 1890-х гг. доля украинцев в целом несколько снижалась. Это прослеживалось по всем трем юго-западным губерниям. Но с 1890-х гг. и до конца империи наблюдалось существенное увеличение доли украинцев среди мировых судей региона. В Киевской и Волынской губерниях к 1913 г. она достигла 3/5 всего состава, по региону в целом - более половины. Это было примерно на треть ниже уровня представительства украинцев среди всего населения в целом, но существенно выше уровня представительства среди городского населения и лиц, имеющих образование выше начального.

Снижение доли украинцев в 1870-е - 1880-е гг. очевидным образом связано с усилением квалификационных требований к судьям, преимущественным заполнением вакансий лицами с высшим юридическим образованием. В эти годы местных кадров соответствующего уровня не хватало. Но затем, с 1890-х гг., региональные университеты выпускали все больше юристов, являющихся уроженцами украинских губерний. Среди них было все больше выходцев из средних и низших сословных групп города и деревни. Проанализированные статистические и описательные данные наглядно показывают, что с конца XIX в. одновременно усиливались процессы демократизации состава судей, увеличивалась доля профессионалов-юристов - выпускников региональных вузов, увеличивалась доля украинцев - выходцев из украинских лево-, правобережных и новороссийских губерний. Отсюда можно сделать вывод о складывании к началу XX в. регионального корпуса профессиональных мировых судей, стабилизации его состава в рамках региона (понимая под регионом все украинские губернии). Судейский корпус во все большей степени сочетал профессиональную и региональную идентичность. Профессиональные коммуникации сочетались с привязанностью к региону, хорошим знанием региональных и местных реалий. Это в свою очередь отражалось на росте востребованности, в том числе городским и сельским простонародьем мировой юстиции как ближайшего и доступного общегражданского суда.

Доступ к судейским должностям был закрыт для крупнейших меньшинств региона - евреевиудеев и поляков-католиков. Частичной компенсацией этого была активность евреев в качестве частных поверенных, в том числе в качестве адвокатов при мировых съездах. Поляки, кроме активности на адвокатском поприще, могли также занимать места почетных мировых судей и низших служащих при судах. В этом качестве представители польского населения развивали, как правило, значительную активность. Многие из них, как местные уроженцы, знатоки округа и его населения, а также люди с хорошим образованием, оказывали позитивное влияние на местную мировую юстицию. На отмеченных доступных позициях евреи и поляки вносили существенный вклад в процессы взаимной адаптации мировой юстиции и этноконфессиональных сообществ региона.

\section{6. Благодарности}

Исследование выполнено при финансовой поддержке РФФИ в рамках научного проекта № 20о9-о0353. Выражаю благодарность Г.Ш. Григоряну за консультацию по реконструкции этнического состава на основании антропонимики.

\section{Литература}

Верняев, 2021 - Верняев И.И. Историческая динамика судебно-правовой интеграции Российской империи. СПб., 2021. 396 с.

Захарьин, 1900 - Захарьин И.Н. Жизнь, служба и приключения мирового судьи. Из записок и воспоминаний. СПб.,1900. 445 с.

Качиони, 1916 - Качиони С.А. Силуэты прошлого: судебно-бытовые очерки // Голос минувщего. № 5-6. M., 1916. C. 189-234.

Кузьмин, 2018 - Кузьмин А.Д. Конфессиональный и национальный состав чиновничества белорусских губерний в 1864-1914 гг. // Вестник Полоцкого университета. Серия А «Гуманитарные науки». 2018. № 1. С. 81-88. 
Миронов, 2021 - Миронов Б.Н. Этническая дискриминация при формировании органов государственной власти СССР // Новейшая история России. 2021. Т. 11. № 1. С. 149-173.

Модзалевский, 1908-1914 - Модзалевский В.Л. Малороссийский родословник. Т. 1-4. Киев, 1908-1914.

П.П., 1883 - П.П. О почетных мировых судьях в Северо-Западном крае // Русъ. 1883. № 8. С. $61-63$.

Панченко, 2013 - Панченко В.С. Мировой судья в Российской империи: профессиональные и личностные характеристики (на примере Волынской губернии) // Вестник Оренбургского государственного педагогического университета. 2013. № 2 (6). С. 110-119.

Первая Всеобщая перепись. Т. 16, 1904 - Первая Всеобщая перепись населения Российской империи, 1897 г. Т. 16. Киевская губерния. СПб., 1904. 288 с.

Первая Всеобщая перепись. Т. 32, 1904 - Первая Всеобщая перепись населения Российской империи, 1897 г. Т. 32. Подольская губерния. СПб., 1904. 286 с.

Первая Всеобщая перепись. Т. 8, 1904 - Первая Всеобщая перепись населения Российской империи, 1897 г. Т. 8. Волынская губерния. СПб., 1904. 282 с.

РГИА - Российский государственный исторический архив.

Редько, 1966 - Редъко Ю.К. Сучасні українські прізвища. Київ, 1966. 216 с.

Список чинам, 1872 - Список чинам ведомства Министерства юстиции за 1872 г. Ч. 2. СПб., 1872.

Список чинам, 1880 - Список чинам ведомства Министерства юстиции за 1880 г. Ч. 3. СПб., 1880.

Список чинам, 1890 - Список чинам ведомства Министерства юстиции за 1890 г. СПб., 1890.

Список чинам, 1900 - Список чинам ведомства Министерства юстиции за 1900 г. СПб., 1900.

Список чинам, 1910 - Список чинам Министерства юстиции за 1910 г. СПб., 1910.

Список чинам, 1913 - Список чинам ведомства Министерства юстиции за 1913 г. СПб., 1913.

Унбегаун, 1989 - Унбегаун Б.О. Русские фамилии. М., 1989. 440 с.

Щербина, 1974 - Щербина П.Ф. Судебная реформа 1864 года на Правобережной Украине. Львов, 1974. 240 с.

Mironov, 2020 - Mironov B.N. Ethnopolitical Discrimination in the late Imperial and Early Soviet Periods // Bylye gody. 58(4): 2798-2808.

Velychenko, 1995 - Velychenko S. Identities, Loyalties and Service in Imperial Russia: Who Administered the Borderlands? // The Russian Review. 54(2): 188-208.

\section{References}

Kachioni, 1916 - Kachioni, S.A. (1916) Siluety proshlogo: sudebno-bytovye ocherki [Outlines of the past: judicial essays]. Golos minuvshego. 5-6: 189-234. [in Russian]

Kuz'min, 2018 - Kuz'min, A.D. (2018). Konfessional'nyi i natsional'nyi sostav chinovnichestva belorusskikh gubernii v 1864-1914 gg. [Professional and national composition of the officialdom of the Belarusian provinces in 1864-1914]. Vestnik Polotskogo universiteta. Seriya A. Gumanitarnye nauki. 1: 81-88. [in Russian]

Mironov, 2020 - Mironov, B.N. (2020). Ethnopolitical Discrimination in the late Imperial and Early Soviet Periods. Bylye gody. 58(4): 2798-2808.

Mironov, 2021 - Mironov, B.N. (2021). Etnicheskaya diskriminatsiya pri formirovanii organov gosudarstvennoi vlasti SSSR [Ethnic Discrimination in the Formation of State Bodies of the USSR]. Modern History of Russia. 11 (1): 149-173. [in Russian]

Modzalevskii, 1908-1914 - Modzalevskii, V.L. (1908-1914). Malorossiiskii rodoslovnik [Little Russian Genealogical Directory]. Vol. 1-4. Kïv. [in Russian]

P.P., 1883 - P.P. (1883) O pochetnykh mirovykh sud'yakh v Severo-Zapadnom krae [On Honorary Justices of the Peace in the north-western provinces]. Rus'. 8: 61-63. [in Russian]

Panchenko, 2013 - Panchenko, V.S. (2013) Mirovoi sud'ya v Rossiiskoi imperii: professional'nye i lichnostnye kharakteristiki (na primere Volynskoi gubernii) [Justice of the Peace in the Russian Empire: professional and personal characteristics (by the example of Volynsky province)]. Vestnik Orenburgskogo gosudarstvennogo pedagogicheskogo universiteta. 2(6): 110-119. [in Russian]

Pervaya Vseobshchaya perepis'. T. 32, 1904 - Pervaya Vseobshchaya perepis' naseleniya Rossiiskoi imperii, 1897 g. T. 32. Podol'skaya guberniya [The First General Census of the Russian Empire, 1897 Vol. 32. Podolsk province]. Petersburg, 1904. 286 p. [in Russian]

Pervaya Vseobshchaya perepis'. T. 8, 1904 - Pervaya Vseobshchaya perepis' naseleniya Rossiiskoi imperii, 1897 g. T. 8. Volynskaya guberniya [The First General Census of the Russian Empire, 1897 Vol. 8. Volyn province]. Petersburg, 1904. 282 p. [in Russian]

Pervaya Vseobshchaya perepis'. Vol. 16, 1904 - Pervaya Vseobshchaya perepis' naseleniya Rossiiskoi imperii, 1897 g. T. 16. Kievskaya guberniya [The First General Census of the Russian Empire, 1897 Vol. 16. Kiev province]. Petersburg, 1904. 288 p. [in Russian]

Red'ko, 1966 - Red'ko, Yu.K. (1966) Suchasni ukraïns'ki prizvishcha [Modern Ukrainian surnames]. Kiev. 216 p. [in Ukrainian]

RGIA - Rossiiskii gosudarstvennyi istoricheskii arkhiv [Russian state historical archive]. 
Shcherbina, 1974 - Shcherbina, P.F. (1974). Sudebnaya reforma 1864 goda na Pravoberezhnoi Ukraine [Judicial reform of 1864 in Right-Bank Ukraine]. L'vov. 240 p. [in Russian]

Spisok chinam, 1872 - Spisok chinam vedomstva Ministerstva yustitsii za 1872 g. Ch. 2 [List of Ministry of Justice officials. 1872. Part 2]. Petersburg, 1872. [in Russian]

Spisok chinam, 1880 - Spisok chinam vedomstva Ministerstva yustitsii za 1880 g. Ch. 3 [List of Ministry of Justice officials. Part 3]. Petersburg, 1880. [in Russian]

Spisok chinam, 1890 - Spisok chinam vedomstva Ministerstva yustitsii za 1890 g. [List of Ministry of Justice officials. 1890]. Petersburg, 1890. [in Russian]

Spisok chinam, 1900 - Spisok chinam vedomstva Ministerstva yustitsii za 1900 g. [List of Ministry of Justice officials. 1900]. Petersburg, 1900. [in Russian]

Spisok chinam, 1910 - Spisok chinam Ministerstva yustitsii za 1910 g. [List of Ministry of Justice officials. 1910]. Petersburg, 1910. [in Russian]

Spisok chinam, 1913 - Spisok chinam vedomstva Ministerstva yustitsii za 1913 g. [List of Ministry of Justice officials. 1913]. Petersburg, 1913. [in Russian]

Unbegaun, 1989 - Unbegaun, B.O. (1989) Russkie familii [Russian surnames]. Moscow. 440 p. [in Russian]

Velychenko, 1995 - Velychenko, S. (1995). Identities, Loyalties and Service in Imperial Russia: Who Administered the Borderlands? The Russian Review. 54(2): 188-208.

Vernyaev, 2021 - Vernyaev, I.I. (2021). Istoricheskaya dinamika sudebno-pravovoi integratsii Rossiiskoi imperii [Historical dynamics of judicial and legal integration of the Russian Empire]. Petersburg. 396 p. [in Russian]

Zakhar'in, 1900 - Zakhar'in, I.N. (1900). Zhizn', sluzhba i priklyucheniya mirovogo sud'i. Iz zapisok i vospominanii [Life, service, and adventures of the Justice of the Peace. Notes and memoirs]. Petersburg. 445 p. [in Russian]

\section{Профессионализация, демократизация и «коренизация» корпуса мировых судей Юго-Западного края в позднеимперской России}

Игорь Иванович Верняев а, *

a Санкт-Петербургский государственный университет, Санкт-Петербург, Российская Федерация

Аннотация. В губерниях Юго-Западного края (Киевская, Волынская, Подольская) мировой суд просуществовал 45 лет с 1872 г. до конца империи. Одним из основных факторов функционирования мировой юстиции был полиэтноконфессиональный характер края. В таком контексте имперский центр ввел систему назначения мировых судей, ограничил доступ к этим должностям католикам и закрыл иудеям. Кадровое обеспечение мировой юстиции стало особым вызовом для судебного ведомства. Судьи должны были одновременно соответствовать ряду значимых критериев: быть профессионалами, обладать знанием специфики края, сохранять лояльность имперскому центру. Динамика основных характеристик профессионального корпуса мирового суда исследована на большом объеме статистических и нарративных материалов. Сочетание статистической обработки данных и анализа описательных источников позволило сделать вывод о том, что в конце XIX - начале XX вв. происходило три взаимосвязанных процесса: 1) судейский корпус мировой юстиции становился все более демократическим по составу, в нем появлялось все больше выходцев из средних и низших сословных групп города и деревни; одновременно резко сокращалась доля выходцев из дворянства; 2) судейский корпус становился все более профессиональным, к 1913 г. подавляющее большинство судей имело высшее юридическое образование, большинство из них получили образование в региональных университетах; 3) с 1890-х гг. происходило увеличение доли украинцев по происхождению среди мировых судей, шел интенсивный процесс коренизации судейского корпуса. К началу XX в. сформировался корпус судей-профессионалов, тесно связанных в личном, образовательном и карьерном отношении с регионом (в широком смысле, включая все украинские губернии). В статье выявлены факторы и механизмы изменений и их результаты.

Ключевые слова: Российская империя, Юго-Западный край, мировой суд, изменения сословного, образовательного, конфессионального и этнического состава судейского корпуса, коренизация и профессионализация судебной сферы.

\footnotetext{
${ }^{*}$ Корреспондирующий автор

Адреса электронной почты: i.verniaev@spbu.ru (И.И. Верняев) 